\title{
Editorial \\ New Frontiers towards Regeneration of the Intervertebral Disc: On Progenitor Cells, Growth Factors and Biomaterials
}

\author{
Benjamin Gantenbein ${ }^{1,2}$ (D) \\ 1 Tissue Engineering for Orthopaedics \& Mechanobiology (TOM), Bone \& Joint Program, Department for \\ BioMedical Research (DBMR), Faculty of Medicine, University of Bern, CH-3008 Bern, Switzerland; \\ benjamin.gantenbein@dbmr.unibe.ch; Tel.: +41-31-632-88-15 \\ 2 Department of Orthopaedic Surgery and Traumatology, Inselspital, Bern University Hospital, \\ University of Bern, CH-3010 Bern, Switzerland
}

check for

updates

Citation: Gantenbein, B. New Frontiers towards Regeneration of the Intervertebral Disc: On Progenitor Cells, Growth Factors and Biomaterials. Appl. Sci. 2021, 11, 11913. https://doi.org/10.3390/ app112411913

Received: 8 December 2021

Accepted: 13 December 2021

Published: 15 December 202

Publisher's Note: MDPI stays neutral with regard to jurisdictional claims in published maps and institutional affiliations.

Copyright: (C) 2021 by the author. Licensee MDPI, Basel, Switzerland. This article is an open access article distributed under the terms and conditions of the Creative Commons Attribution (CC BY) license (https:// creativecommons.org/licenses/by/ $4.0 /)$.

\begin{abstract}
This Special Issue on intervertebral disc (IVD) regeneration focuses on novel advances in understanding the cell sources and culture conditions of various cell types, i.e., progenitor and IVD cells. The issue consists of seven articles that provide a comprehensive overview of recently applied research insights: (1) into how IVD herniation can be provoked in a controlled in vitro biomechanical testing set-up, (2) how cells can be used for IVD repair, (3) the physiological conditions of IVD cells and (4) how hyaluronic acid could be used for IVD repair, and (5) how nucleus pulposus progenitor cells (NPPCs) and mesenchymal stromal cells (MSCs) shall be cultured and expanded towards a possible cell therapy.
\end{abstract}

Keywords: biomaterials; tissue engineering; progenitor cells; cell therapy; biomechanics; lumbar disc herniation; GDF5; GDF6; TGF $\beta$; nucleus pulposus progenitor cells (NPPC); losartanon

\section{Introduction}

Current approaches to regenerate the entire IVD or parts of IVDs are not very successful. Lower back pain (LBP) is a dominant medical problem that affects billions of people worldwide, yet no cure is in close sight. Orthopedic surgery often removes the affected motional segment by so-called "discectomy" and tries to fuse the two adjacent segments to achieve stability, possibly removing the LBP. However, tissue-engineered solutions have been developed to target a biological and, hopefully, more physiological solution to the problem. This Special Issue provides a cross-disciplinary section of "applied science" in this field of biomedical research ranging from biomechanics [1], biomaterials such as hyaluronic acid (HA) [2], and cell physiology [3] to in vitro cell culture studies on how cell phenotypes should be directed towards more IVD-like cells [4-6]. Traditionally, three tissue types are distinguished of the IVD, i.e., the nucleus pulposus (NP), the annulus fibrosus (AF), and the cartilaginous endplates (CEP) [7]. Thus, the articles partially focus on the generation of in vitro NP cells and how to provide a micro-environment for these [2]. In addition, an innovative approach is presented regarding how Angiotensin II Type 1 Receptor Antagonist "Losartanon" could be used to partially reverse inflammation caused by tumor necrosis factor alpha $(\mathrm{TNF} \alpha)[4]$.

\section{Highlights on the Studies Published in the Present Special Issue: Intervertebral Disc Regeneration}

The first highlight to mention is the valuable contribution of the group of Prof. HansJoachim Wilke and his team on how the process of lumbar disc herniation can be provoked using in vitro biomechanical testing protocols [1]. Wilke et al. (1999) [8] provided essential knowledge on the in vivo physiological loading patterns in human IVDs following the first observations by Nachemson [9] in 1966. In this Special Issue for the first time, a successful 
loading regime is presented that can reproduce the herniation of NP material from the inner part of the IVD as in the clinical situation [1].

Furthermore, two excellent reviews are presented in this Special Issue: one is on the usage of HA for the application of IVD regeneration by the group of Prof. Abhay Pandit [2]. This group is extremely knowledgeable on various aspects of biomaterials for multiple applications in musculoskeletal regeneration and provides an excellent review of the studies involving HA for IVD repair. The second review focuses on progress using many allogeneic progenitor cells for cell therapy in ongoing clinical trials by Prof. Inbo Han and his team [10]. Furthermore, two studies were published by Prof. Daisuke Sakai and his team around progenitor cells [5,6]. One manuscript by Sako et al. (2021) [5] reports an exciting approach how NPPCs can be better kept in culture using specialized spheroid culture systems. The second study by the same laboratory team then reports on in vitro screening for the most suitable combination of cytokines to differentiate MSCs towards NP-like cells [6]. This discussion on how to obtain NP-like cells from progenitors, of course, already began much earlier and can be read in more detail in many other articles presented by other research groups, e.g., [11-13]. It was exciting to learn that a combination of growth and differentiation factor 5 (GDF5) and transforming growth factor beta 1 (TGF $\beta 1$ ) was the most promising combination towards an NP-like phenotype.

Funding: The author wishes to acknowledge his current funding sources: This research was enabled by the Swiss National Science Foundation project \#310030E_192674/1 (https:/ / p3.snf.ch/project-19 2674, accessed on 1 December 2021). Further funds were received from the iPSpine H2020 project under the grant agreement \#825925 (https:/ / cordis.europa.eu/project/id/825925, assessed on 1 December 2021) and by funds from the Marie Skłodowska Curie International Training Network (ITN) “disc4all” (https:/ / cordis.europa.eu/project/id/955735, accessed on 1 December 2021). Hans Joachim Wilke acknowledges his funding by the German Spine Foundation and partially by the German Research Foundation (WI 1352/14-3).

Institutional Review Board Statement: Not applicable.

Informed Consent Statement: Not applicable.

Data Availability Statement: Not applicable.

Acknowledgments: This publication was only possible with the valuable contributions from the authors, reviewers, and the editorial team of Applied Sciences, with special thanks to Frederic Yuan, who was very motivating and supportive.

Conflicts of Interest: The author is a guest editor of the present Special Issue and has no other conflict of interest with any of the published contents of the Special Issue articles.

\section{References}

1. Zengerle, L.; Debout, E.; Kluger, B.; Zöllner, L.; Wilke, H.-J. In Vitro Model for Lumbar Disc Herniation to Investigate Regenerative Tissue Repair Approaches. Appl. Sci. 2021, 11, 2847. [CrossRef]

2. Kazezian, Z.; Joyce, K.; Pandit, A. The Role of Hyaluronic Acid in Intervertebral Disc Regeneration. Appl. Sci. 2020, $10,6257$. [CrossRef]

3. Borrelli, C.; Buckley, C.T. Synergistic Effects of Acidic pH and Pro-Inflammatory Cytokines IL-1 $\beta$ and TNF- $\alpha$ for Cell-Based Intervertebral Disc Regeneration. Appl. Sci. 2020, 10, 9009. [CrossRef]

4. Saravi, B.; Li, Z.; Pfannkuche, J.; Wystrach, L.; Häckel, S.; Christoph, C.; Grad, S.; Alini, M.; Richards, R.G.; Lang, C.; et al. Angiotensin II Type 1 Receptor Antagonist Losartan Inhibits TNF- $\alpha$-Induced Inflammation and Degeneration Processes in Human Nucleus Pulposus Cells. Appl. Sci. 2021, 11, 417. [CrossRef]

5. Sako, K.; Sakai, D.; Nakamura, Y.; Matsushita, E.; Schol, J.; Warita, T.; Horikita, N.; Sato, M.; Watanabe, M. Optimization of Spheroid Colony Culture and Cryopreservation of Nucleus Pulposus Cells for the Development of Intervertebral Disc Regenerative Therapeutics. Appl. Sci. 2021, 11, 3309. [CrossRef]

6. Morita, K.; Schol, J.; Volleman, T.N.E.; Sakai, D.; Sato, M.; Watanabe, M. Screening for Growth-Factor Combinations Enabling Synergistic Differentiation of Human MSC to Nucleus Pulposus Cell-Like Cells. Appl. Sci. 2021, 11, 3673. [CrossRef]

7. Cassidy, J.J.; Hiltner, A.; Baer, E. Hierarchical structure of the intervertebral disc. Connect. Tissue Res. 1989, 23, 75-88. [CrossRef] [PubMed]

8. Wilke, H.J.; Neef, P.; Caimi, M.; Hoogland, T.; Claes, L.E. New in vivo measurements of pressures in the intervertebral disc in daily life. Spine 1999, 24, 755-762. [CrossRef] [PubMed] 
9. Nachemson, A. The load on lumbar disks in different positions of the body. Clin Orthop. Relat. Res. 1966, 45, 107-122. [CrossRef] [PubMed]

10. Lee, C.K.; Heo, D.H.; Chung, H.; Roh, E.J.; Darai, A.; Kyung, J.W.; Choi, H.; Kwon, S.Y.; Bhujel, B.; Han, I. Advances in Tissue Engineering for Disc Repair. Appl. Sci. 2021, 11, 1919. [CrossRef]

11. Colombier, P.; Clouet, J.; Boyer, C.; Ruel, M.; Bonin, G.; Lesoeur, J.; Moreau, A.; Fellah, B.H.; Weiss, P.; Lescaudron, L.; et al. TGF- $\beta 1$ and GDF5 Act Synergistically to Drive the Differentiation of Human Adipose Stromal Cells toward Nucleus Pulposus-like Cells. Stem Cells 2016, 34, 653-667. [CrossRef] [PubMed]

12. Stoyanov, J.V.; Gantenbein-Ritter, B.; Bertolo, A.; Aebli, N.; Baur, M.; Alini, M.; Grad, S. Role of hypoxia and growth and differentiation factor- 5 on differentiation of human mesenchymal stem cells towards intervertebral nucleus pulposus-like cells. Eur. Cell. Mater. 2011, 21, 533-547. [CrossRef] [PubMed]

13. Clarke, L.E.; McConnell, J.C.; Sherratt, M.J.; Derby, B.; Richardson, S.M.; Hoyland, J.A. Growth differentiation factor 6 and transforming growth factor-beta differentially mediate mesenchymal stem cell differentiation, composition and micromechanical properties of nucleus pulposus constructs. Arthritis Res. 2014, 16, R67. [CrossRef] [PubMed] 